\title{
Equine leukoencephalomalacia (ELEM) due to fumonisins B1 and B2 in Argentina ${ }^{1}$
}

\author{
Federico Giannitti2* , Santiago Sain Diab ${ }^{3}$, Ana Maria Pacin ${ }^{4,5}$, Maria Barrandeguy ${ }^{6}$, \\ Carlos Larrere ${ }^{7}$, Joaquin Ortega ${ }^{3}$ and Francisco Alejandro Uzal ${ }^{3}$
}

\begin{abstract}
Giannitti F., Diab S.S., Pacin A.M., Barrandeguy M., Larrere C., Ortega J. \& Uzal F.A. 2011. Equine leukoencephalomalacia (ELEM) due to fumonisins B1 and B2 in Argentina. Pesquisa Veterinária Brasileira 31(5):407-412. Laboratorio de Diagnóstico Veterinario, calle 25 de Mayo 139, Bahía Blanca (8000), Buenos Aires, Argentina. E-mail: fgiannitti@yahoo.com

In August 2007 an outbreak of neurological disease and sudden death in Arabian horses occurred in a farm located in Coronel Rosales County, Buenos Aires Province, Argentina. The animals were on a pasture of native grasses and supplemented ad libitum with corn kernels and wheat bran. Three horses were observed having acute neurologic signs including blindness, four leg ataxia, hyperexcitability, aimless walking and circling, followed by death in two of them. Four other horses were found dead overnight without a history of neurologic signs. The morbidity, mortality and lethality rates were $11.6 \%, 10 \%$ and $85.7 \%$, respectively. Grossly, the brain showed focal areas of hemorrhage, brown-yellow discoloration and softening of the sub-cortical white matter. The microscopic brain lesions consisted of extensive areas of malacia within the white matter of the cerebral hemispheres, brainstem and cerebellum, characterized by rarefaction of the white matter with cavitations filled with proteinaceous edema, multifocal hemorrhages and mild infiltration by neutrophils, and rare eosinophils. Swollen glial cells with abundant eosinophilic cytoplasm, distinct cell borders, intracytoplasmic deeply eosinophilic globules and eccentric, hyperchromatic, occasionally pyknotic nucleus were present throughout the areas of rarefaction hemorrhage, edema and necrosis. The feed supplements contained $12,490 \mu \mathrm{g} / \mathrm{kg}$ of fumonisin B1 and $5,251 \mu \mathrm{g} /$ $\mathrm{kg}$ of fumonisin B2. This is the first reported outbreak of ELEM associated with consumption of feed supplements containing high concentrations of fumonisins in Argentina.
\end{abstract}

INDEX TERMS: Mycotoxins, horse, equine leukoencephalomalacia, fumonisins, pathology, Argentina.

\footnotetext{
${ }^{1}$ Received on November 23, 2010.

Accepted for publication on December 11, 2010.

${ }^{2}$ Laboratorio de Diagnóstico Veterinario (LDV), calle 25 de Mayo 139, Bahía Blanca (8000), Buenos Aires, Argentina. *Corresponding author: fgiannitti@yahoo.com

${ }^{3}$ California Animal Health and Food Safety Laboratory System (CAHFS), San Bernardino and Davis Branches, University of California Davis, 105 West Central Avenue, San Bernardino (92408), CA, and West Health Science Drive, Davis (95616), CA, USA.

${ }^{4}$ Fundación de Investigaciones Científicas Teresa Benedicta de la Cruz, calle Dorronzoro 141, Luján (B6700), Buenos Aires, Argentina.

${ }^{5}$ Comisión de Investigaciones Científicas de la Provincia de Buenos Aires, calle 526 e/10 y 11, La Plata (1900), Buenos Aires, Argentina.

${ }^{6}$ Instituto Nacional de Tecnología Agropecuaria (INTA), calle De los reseros y Las cabañas s/n (1712), Castelar (1712), Buenos Aires, Argentina.

${ }^{7}$ Veterinarian, Private Practice, Bahía Blanca, Buenos Aires, Argentina.
}

RESUMO.- [Leucoencefalomalacia equina devida a fumonisinas B1 e B2 na Argentina.] Em agosto de 2007, ocorreu um surto de doença neurológica e morte súbita em cavalos árabes em uma propriedade localizada no município de Coronel Rosales, na província de Buenos Aires, Argentina. Os animais estavam em pasto nativo e eram suplementados ad libitum com grãos de milho e farelo de trigo. Três cavalos foram observados com sinais neurológicos agudos, incluindo cegueira, ataxia nas quatro pernas, hiperexcitabilidade, e andar sem rumo e em círculo, seguidos de morte em dois animais. Outros quatro cavalos foram encontrados mortos durante a noite sem histórico de distúrbios neurológicos. A mortalidade, morbidade e letalidade foram de $11,6 \%, 10 \%$ e $85,7 \%$, respectivamente. Macroscopicamente, o cérebro tinha áreas focais de hemorragia, coloração amarelada e amolecimento da subs- 
tância branca sub-cortical. Microscopicamente, as lesões cerebrais consistiram de extensas áreas de malácia na substância branca dos hemisférios cerebrais, do tronco encefálico e do cerebelo. Estas lesões da substância branca se caracterizaram por rarefação, cavidades contendo fluido proteináceo (edema), hemorragias multifocais e moderado infiltrado por neutrófilos e raros eosinófilos. Células gliais tumefeitas com abundante citoplasma eosinifílico, limites celulares evidentes, globules citoplasmáticos eosinofílicos, e núcleo excéntrico, hipercromático e ocasionalmente picnótico foram observadas nas areas de rarefacção, edema, hemorragias e necrose. Os suplementos alimentares continham $12.490 \mu \mathrm{g} / \mathrm{kg}$ de fumonisina B1 e $5.251 \mu \mathrm{g} /$ $\mathrm{kg}$ de fumonisina B2. Este é o primeiro surto reportado na Argentina de leucoencefalomalácia equina associado ao consumo de suplementos alimentares contendo altas concentrações de fumonisinas.

TERMOS DE INDEXAÇÃO: Micotoxinas, cavalo, leucoencefalomalacia equina, fumonisinas, patologia, Argentina.

\section{INTRODUCTION}

Equine leukoencephalomalacia (ELEM), also known as equine mycotoxic encephalomalacia or moldy corn poisoning is a devastating neurologic diseases of equidae characterized by acute central neurological clinical signs associated with liquefactive necrosis of the cerebral sub-cortical white matter. The disease has been reported in several countries and it is caused by ingestion of one or more type of fumonisins (Marasas et al. 1988, Kellerman et al. 1990), mycotoxins produced by several species of fungi of the genus Fusarium, including $F$. proliferatum and $F$. verticillioides (formerly F. moniliforme) (Shephard et al. 1996), that are frequent corn (Zea mays) and corn by-products contaminants (Cawood et al. 1991, Ross et al. 1991). More than 28 types of fumonisins have been isolated and characterized (Rheeder et al. 2002). Of these, fumonisins B1 (FB1), B2 (FB2) and $\mathrm{B} 3$ are the most common in nature and FB1 is the most frequently detected in corn worldwide (Beasley 1999, FDA 2001, Wu 2006) and the most commonly associated with ELEM outbreaks. Fumonisins are responsible for a variety of health problems in several animal species, including humans. These compounds are carcinogenic in laboratory rodents (NTP 2001) and the International Agency for Research on Cancer of the World Health Organization has included them in the list of probable carcinogenic substances for humans (WHO 2002).

Amongst the domestic animals, horses are the most sensitive to fumonisin intoxication, the toxic effects of FB1 in this species being dose-dependent (Foreman et al. 2004). Most naturally occurring cases of ELEM have taken place with feed containing FB1 concentrations above 10,000 $\mu$ g/ $\mathrm{kg}$ (Ross et al. 1991). Affected horses develop acute neurological clinical signs after a variable exposure time, which ranges between 7 and 180 days, or die suddenly and unexpectedly after only mild neurologic clinical alteration or without clinical signs being observed (Wilson et al. 1992,
Beasley 1999, Foreman et al. 2004). The clinical signs include decreased tongue tone and mobility, propioceptive deficit, ataxia, anorexia, lethargy, blindness, circling, aimless walking, head-pressing, hyperexcitability, diaphoresis and coma (Summers et al. 1995, Beasley 1999, Foreman et al. 2004, Maxie \& Youssef 2007). Affected animals that develop clinical signs but survive usually show some degree of neurologic deficit for life (Summers et al. 1995, Beasley 1999, Maxie \& Youssef 2007).

The pathogenesis of ELEM is not yet completely understood. The enzyme sphingosine- $\mathrm{N}$-acyltransferase (whose substrates are sphingosine and fatty acyl-CoA) is structurally inhibited by fumonisins. This enzyme is involved in sphingolipids biosynthesis and it is hypothesized that the accumulation of the enzyme substrates as well as the depletion of complex sphingolipids, may account for the toxicity of these fumonisins (Merril et al. 1996, Beasley 1999).

The characteristic gross lesion of ELEM is restricted to the white matter of the cerebral hemispheres and consists of softening, cavitation and yellow discoloration (leukoencephalomalacia). The lesion may be focal or multifocal, uni or bilateral (Summers et al. 1995), and mild cases may not show gross lesions at all (Beasley 1999). Histologically, the most characteristic lesions consist of areas of liquefactive necrosis, edema and hemorrhage affecting the encephalic white matter (Maxie \& Youssef 2007). A presumptive diagnosis is established based on clinical signs and on gross and/or histological findings. Confirmation of the diagnosis relies on detection of toxic concentrations of fumonisins in feed (Beasley 1999). We describe here a cluster of cases of ELEM in Argentina, a country in which no cases of the disease associated with consumption of fumonisins have been reported before.

\section{MATERIALS AND METHODS}

\section{Clinical history}

In August 2007 an outbreak of neurological disease and sudden death in Arabian horses occurred in a farm located in Coronel Rosales County, Buenos Aires Province, Argentina. A herd of 60, 2 to 4-year-old male Arabian horses was grazing on natural pastures in a 160 hectare paddock. In addition, the animals were supplemented ad libitum with a mixture of corn kernels and wheat bran administered in silo feeders. Within ten days after the horses began consuming the supplement, 4 horses were found dead and 3 others were seen showing acute neurological signs. The animals had been seen the day before by the caretaker and they appeared healthy. The clinical signs of the sick animals were of variable severity and included blindness, circling, aimless walking, ataxia and hyperexcitability. The clinical signs worsened until the horses became laterally recumbent and two of them died $24 \mathrm{~h}$ after the onset of the clinical signs. The third horse, which presented milder clinical signs, was treated with thiamine, antibiotics, dexamethasone and flunixin, and it showed a slow partial recovery. The morbidity, mortality and lethality rates were $11.6 \%, 10 \%$ and $85.7 \%$, respectively.

\section{Laboratory tests}

Post-mortem examinations of one of the horses found dead (Horse \# 1) and one of the animals that had been observed 
presenting neurological signs (Horse \# 2) were performed. Both animals were 3 years old. The estimated elapsed time between death and necropsy was $12 \mathrm{~h}$ and $3 \mathrm{~h}$, respectively. Samples from brain, liver, spleen, kidney, intestine, lung, stomach, heart, lymph node, adrenal gland and urinary bladder were collected and fixed in $10 \%$ neutral buffered formalin for $48 \mathrm{~h}$. The brains were fixed whole for $48 \mathrm{~h}$ after which they were sliced at $\sim 5 \mathrm{~mm}$ intervals and fixed for another $48 \mathrm{~h}$ in fresh formalin, and the following areas were obtained: cortex, brain stem, cerebellum and medulla oblongata. The tissues were embedded in paraffin, sectioned at 5 ìm and stained routinely with hematoxylin and eosin (HE).

A blood sample was collected from Horse \# 2 and the serum was processed by capture ELISA for West Nile Virus (WNV) IgM antibody detection as previously described (Ostlund 2008).

Cerebrospinal fluid (CSF) was collected from both horses and used for WNV IgM antibody detection using the same technique described above for the serum of Horse \# 2 .

From Horse \# 2, a pool of brain tissue (cerebrum, cerebellum and medulla oblongata) was collected and frozen immediately at $-20^{\circ} \mathrm{C}$ until it was processed for virus isolation, and WNV and Equine Herpesvirus 1 (EHV-1) PCR. For virus isolation, brain pool tissue homogenates were inoculated onto RK13 cells; the inoculated cell cultures were observed daily and a blind passage onto new cells was done after 7 days. Polymerase chain reaction (PCR) and reverse transcriptase PCR (RT-PCR) for EHV-1 (Lawrence et al. 1994) and WNV (Johnson et al. 2001) genome detection were performed on DNA and RNA, respectively, extracted from the same tissue homogenates.

Samples from the feed supplement (mixture of corn kernels and wheat bran) were collected and analysed to determine the presence of FB1 and FB2 by liquid chromatography (AOAC 2000). Limits of Detection (LOD) were $10 \mathrm{ng} / \mathrm{g}$ for FB1 and $6 \mathrm{ng} /$ $\mathrm{g}$ for FB2 (Signal-to-noise ratio $=3: 1$ ). Limits of Quantification (LOQ) were 18ng/g for FB1 and 30ng/g for FB2 (Signal-to-noise ratio $=5: 1$ ). Average recoveries at $100,200,400$ and $600 \mu \mathrm{g} / \mathrm{kg}$ of spiked sample were greater than $99 \%$ for FB1 and the same level for FB2 was $103 \%$. The precision of the methods was calculated in terms of relative standard deviation and were ranged between 7.5 and $17.0 \%$ for both fumonisins.

\section{RESULTS}

\section{Pathological findings}

Both necropsied horses were in very good nutritional condition, and in a mild to moderate state of post-mortem decomposition. Grossly, the brain of Horse \# 2 had multiple to coalescing foci of hemorrhage, brown-yellow discoloration and softening of the sub-cortical cerebral white matter. No gross lesions were found in the brain of Horse \# 1. The urinary bladder mucosa of Horse \# 2 was diffusely reddened. The only other gross findings observed in these two horses consisted of multifocal, shallow, chronic ulcerations and presence of numerous larvae of Gasterophilus sp. attached to the non-glandular gastric mucosa.

Histological lesions were seen in the cerebral hemispheres, brainstem and cerebellum only and they were similar in both animals (Horses \# 1 and 2). They consisted of extensive multifocal to coalescing areas of white matter rarefaction and necrosis, which occasionally extended into the adjacent gray matter. Affected white matter had severe eosinophilic proteinaceous edema, with scattered eosino- philic globules, and/or multifocal areas of hemorrhage. Throughout the areas of rarefaction, hemorrhage, edema and necrosis there were: (1) swollen astrocytes with large, vesicular nuclei; (2) a moderate number of activated glial cells with abundant eosinophilic cytoplasm, well-demarcated cell boundaries, frequently containing intracytoplasmic, deeply eosinophilic, small globules and occasionally eccentric, hyperchromatic sometimes pyknotic nucleus (Fig. 4); (3) scattered neutrophils; and (4) rare eosinophils. Vascular changes were present in small arteries and veins within the areas of rarefaction and necrosis, and included hypertrophy and degeneration of the vascular endothelium, perivascular edema and hemorrhage, and thrombosis. Occasionally, there were perivascular cuffs consisting of a low to moderate number of lymphocytes, histiocytes, fewer neutrophils and rare eosinophils (Fig.1-6). The urinary bladder of Horse \# 2 had severe, acute, diffuse, subepithelial hemorrhage. No other significant histological abnormalities were observed.

\section{Toxicology}

The feed supplement appeared grossly normal and no evidence of mold was observed. Determination of fumonisins by the liquid chromatographic method revealed a concentration of $12,490 \mu \mathrm{g} / \mathrm{kg}$ of $\mathrm{FB} 1$ and $5,251 \mu \mathrm{g} / \mathrm{kg}$ of FB2.

\section{Virology}

No cytopathic viruses were isolated from brain tissue pool of Horse \# 2; RT-PCR for EHV-1 and PCR for WNV genome detection resulted negative. No WNV IgM antibodies were detected in blood serum or CSF of Horse \# 2.

\section{DISCUSSION}

Acute central neurological disease in horses can be caused by several viruses (e.g. WNV, EHV-1 and encephalitides viruses), protozoa (e.g. Sarcocystis neurona), bacteria (e.g. Listeria spp.), trauma and toxic substances (e.g. fumonisins and yellow starthistle - Centaurea solstitialis - intoxication). In this case, infectious encephalitides were ruled out by histology and also by the negative result of virus isolation. WNV and EHV-1 were also ruled out by the negative results of the PCR specific for these diseases and, in the case of WNV, by the negative serological results. No evidence of trauma was evident on necropsy.

The gross and histological features of ELEM, including the anatomical location of these changes are very characteristic of this condition. In this study a preliminary diagnosis of ELEM was established based on the gross lesions in the brain of Horse \# 2 and on the histological changes observed in the brain of both horses. This diagnosis was confirmed by detection of toxic concentrations of FB1 and FB2 $(17,741 \mu \mathrm{g} / \mathrm{kg})$ in the feed supplement that the animals were eating. This value is well over the amount of fumonisin considered toxic for horses. Most naturally occurring cases of ELEM have been seen in animals eating feedstuff with fumonisins concentrations above $10,000 \mu \mathrm{g} / \mathrm{kg}$ (Ross et al. 1991, Wilson et al. 1992). 


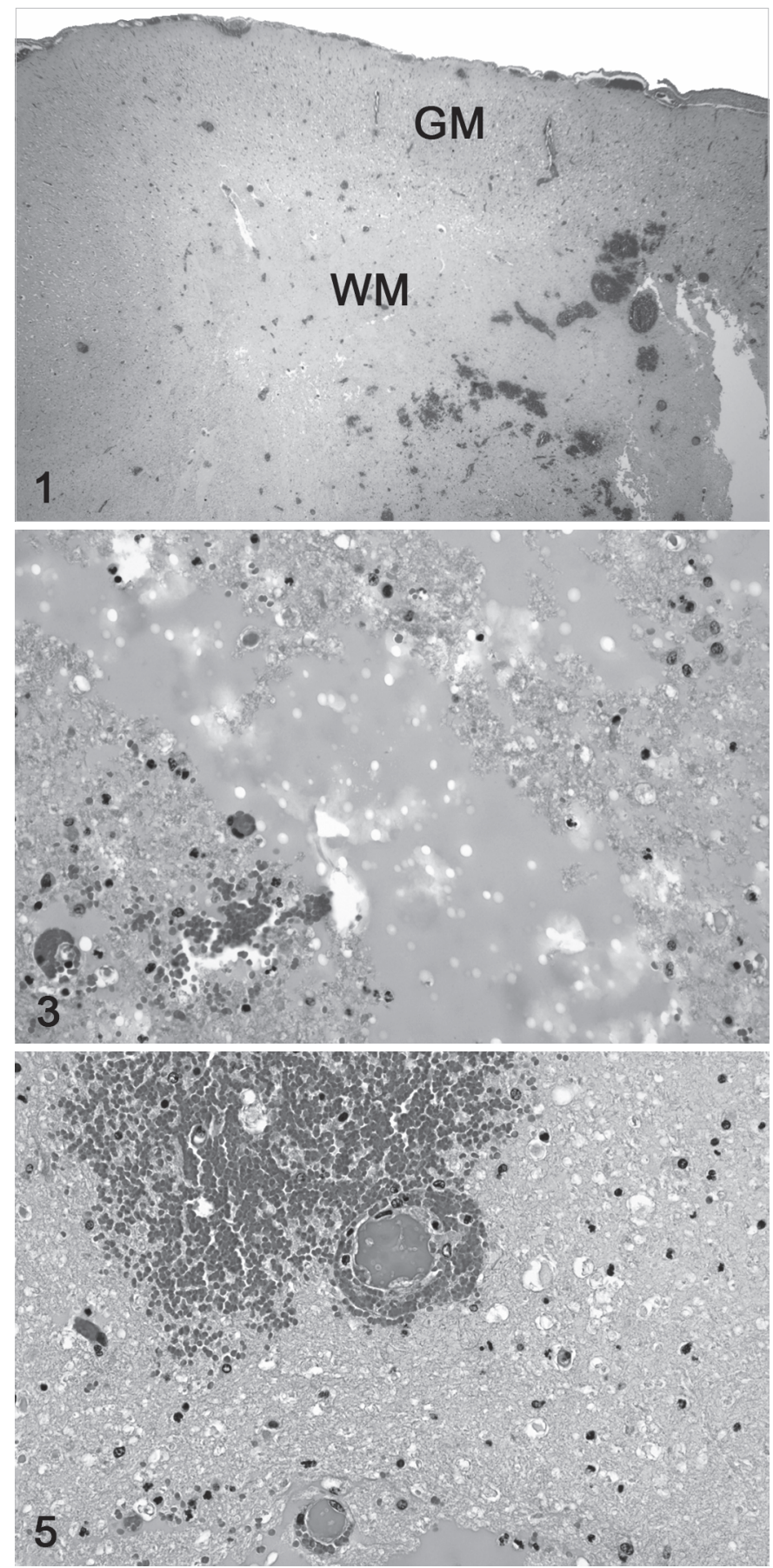

Fig.1. Cerebral cortex, horse \# 2. Areas of malacia and hemorrhage affecting the white matter (WM) and sparing the gray matter (GM). HE, 20x.

Fig.3. Cerebral cortex, horse \# 2. Abundant, eosinophilic homogeneous material (edema) and hemorrhage within the white matter. HE, 400x.

Fig.5. Cerebral cortex, horse \# 2. Vascular thrombosis and perivascular hemorrhage within the white matter. H\&E, 600x.
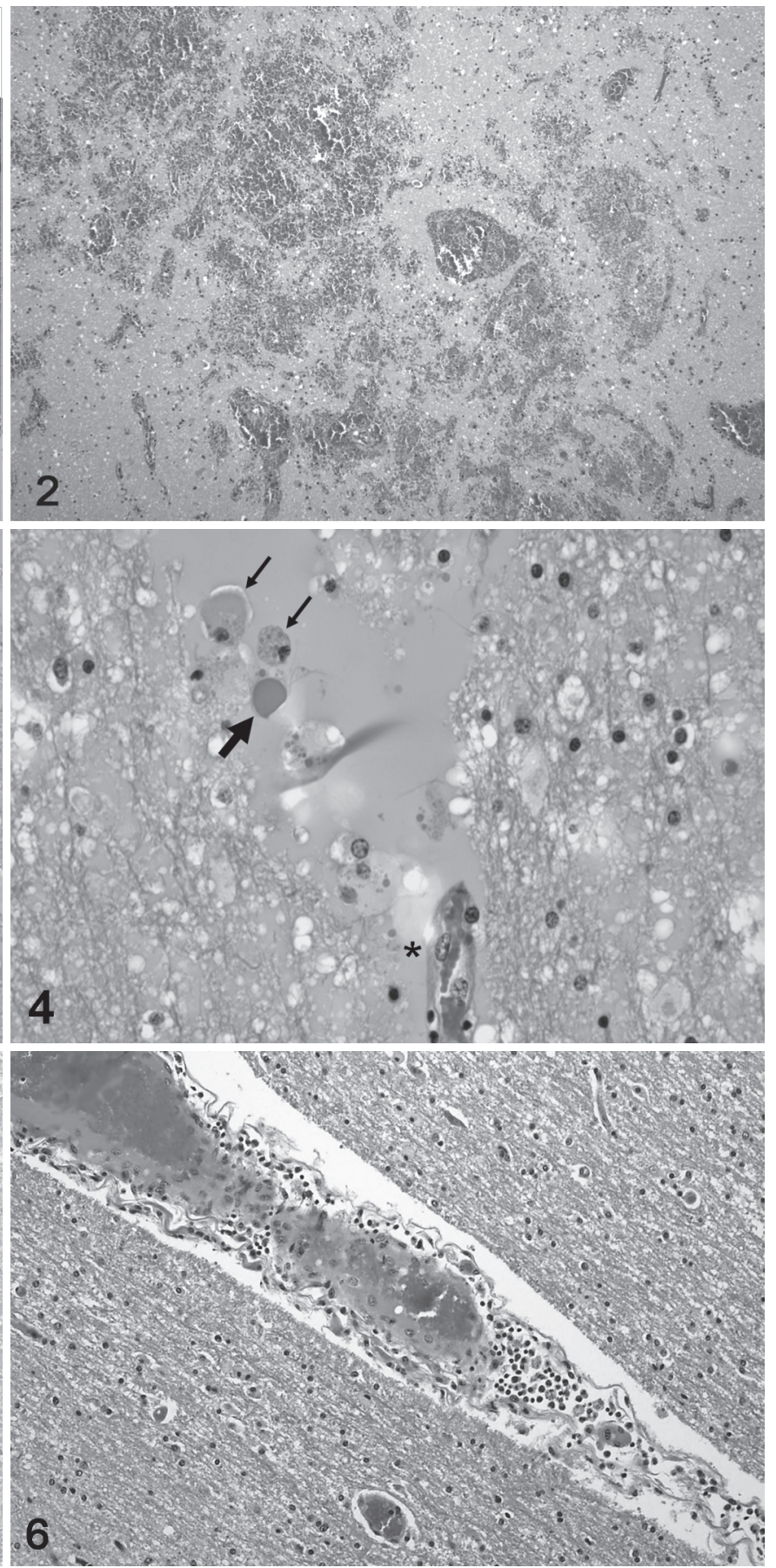

Fig.2. Brainstem, horse \# 2. Multifocal, severe hemorrhage. HE, 20x.

Fig.4. Cerebral cortex, horse \# 2. White matter malacia with edema and extracytoplasmic eosinophilic globules (thick arrow), reactive glial cells with abundant eosinophilic cytoplasm, distinct cell borders, intracytoplasmic deeply eosinophilic globules and eccentric hyperchromatic nucleus (thin arrows), and hypertrophied vascular endothelium $\left(^{*}\right)$. HE, 600x.

Fig.6. Cerebral cortex, horse \# 2. Perivascular inflammatory infiltrate. HE, 600x. 
To the best of our knowledge, lesions compatible with ELEM were diagnosed only once before in Argentina (Monina et al. 1981). However in that case the diagnosis was established based on clinical signs, gross and histological findings, and isolation of Aspergillus flavus, Penicillum spp., and Fusarium spp. from feed, but no measurement of fumonisins was performed. Isolation of Fusarium spp. from feed samples is no longer considered of diagnostic significance since this fungus is a frequent contaminant of corn and it does not always produce fumonisins (Uhlinger 1997, Beasley 1999, Galey 2009).

In the previous case reported in Argentina by Monina et al. (1981) the authors describe the presence of sub-epithelial hemorrhage in the urinary bladder which was also present in one of the horses in our study. These lesions have been previously reported to occur in ELEM confirmed cases (Rooney \& Robertson 1996).

The swollen glial cells with abundant eosinophilic cytoplasm, distinct cell borders, intracytoplasmic deeply eosinophilic globules and eccentric, hyperchromatic, occasionally pyknotic nucleus present throughout the areas of hemorrhage, edema and necrosis are referred to as oligodendrocytes or clasmatodendritic astroglia in the human pathology literature. It has been proposed that these macroglial cells incorporate plasma proteins and edema fluid that have been released into the brain parenchyma around areas of hemorrhage and phagocytose cellular debris in patients with cerebrovascular disease, which likely represents a homeostatic mechanism that tends to maintain the composition of the extracellular environment (Tomimoto et al. 1997, Del Bigio et al. 2000). The presence of this cell type has been previously described in cases of leukoenephalomalacia in horses (Riet-Correa et al. 1998, Câmara et al. 2008) and mules (Riet-Correa et al. 2007, Câmara et al. 2008).

Several authors reported a seasonal occurrence of ELEM with a peak of cases occurring between late fall to early spring (Rooney \& Robertson 1996, Riet-Correa et al. 1998). This is consistent with the time of the year when the currently reported case occurred (August; middle of the winter in the Southern hemisphere).

ELEM cases have also been associated to wet climate conditions during the corn production period (Barros et al. 1984, Rooney \& Robertson 1996). In our case no information about year of harvesting and storage conditions of the corn was available.

Although most fumonisins are produced by fungi of the genus Fusarium, other fungi such as Aspergillus niger (Frisvad et al. 2007) and Alternaria alternata (Abbas \& Riley 1996, Mirocha et al. 1996), are capable of producing FB1 and FB2. Although it is most likely that the fumonisins detected in the feed in this case were produced by Fusarium spp., fungal culture of the feed was not performed and we cannot completely rule out that these compounds were produced by fungi other than Fusarium spp. To the best of our knowledge cases of ELEM caused by fumonisins produced by fungi different than Fusarium spp. are not reported.
ELEM is not frequently reported in Argentina despite the high frequency of fumonisins contamination detected in corn and corn by-products destined to animal and human consumption in this country (Solovey et al. 1999, Broggi et al. 2002, Broggi et al. 2007, Pacin et al. 2009). This situation may be due to the low frequency with which corn is used to feed horses or to the limited number of horse necropsies and/or toxicological studies performed, which are necessary to confirm the diagnosis.

\section{CONCLUSIONS}

This is the first confirmed outbreak of ELEM in Argentina in which toxic levels of fumonisins were detected in feed. Nevertheless, we believe the disease may be under-reported and it should be an important differential diagnosis in horses that develop acute neurologic signs and are consuming feedstuffs containing corn. Findings in this report emphasize the importance of detection of fumonisins and other mycotoxins related to health problems in feeds destined to animal and human consumption. This and other mycotoxicoses should not be underestimated in animal production systems, mainly those using grains and cereals as feedstuffs.

Acknowledgements.- The authors wish to thank Dr. Ingeborg Langohr from Michigan State University, and Gabriela Cano and Daniela Taglieri from "Comisión de Investigaciones Científicas de la Provincia de Buenos Aires" for their technical assistance.

\section{REFERENCES}

Abbas H.K. \& Riley R.T. 1996. The presence and phytotoxicity of fumonisins and AAL-toxin in Alternaria alternata. Toxicon 34:133-136.

AOAC International 2000. AOAC-IUPAC (1998) AOAC Official Method 995.15 Fumonisins B1, B2, and B3 in corn. Liquid Chromatographic Method, AOAC-IUPAC Method, First Action 1995, Revision March 1998.

Barros C.S.L., Barros S.S., Dos Santos M.N. \& Souza M.A. 1984. Leucoencefalomalacia em equinos no Rio Grande do Sul. Pesq. Vet. Bras. 4:101-107.

Beasley V. 1999. Toxicants with mixed effects on the central nervous system. In: Ibid. (Ed.), Veterinary Toxicology <http://www.ivis.org/ advances/Beasley/toc.asp> International Veterinary Information Service (IVIS), Ithaca, NY (www.ivis.org).

Broggi L.E., Pacin A.M., Gasparovic A., Sacchi C., Rothermel A., Gallay A. \& Resnik S.L. 2007. Natural occurrence of aflatoxins, deoxynivalenol, fumonisins and zearalenone in maize from Entre Rios Province, Argentina. Mycotoxin Res. 23(2):59-64

Broggi L.E., Resnik S.L., Pacin A.M., González H.H.L., Cano G. \& Taglieri D. 2002. Distribution of fumonisins in dry-milled corn fractions in Argentina. Food Additives and Contaminants 19(5):465-469.

Câmara A.C.L., Bastos Alfonso J.A., Riet-Correa F., Dantas A.F.M., Lopes de Mendonça C., de Acevêdo Costa N., Cruz Dantas A., Araújo Costa Neto H., Silva Siqueira Campos A.G. \& de Souza M.I. 2008. Leucoencefalomalácia em eqüídeos no estado de Pernambuco. Ciência Animal Brasileira. 9(2):470-479.

Cawood M.E., Gelderblom W.C.A., Vlegaar R., Behrend Y., Thiel P.G. \& Marasas W.F.O. 1991. Isolation of the fumonisin mycotoxins: A quantitative approach. J. Agric. Food Chem. 39:1958-1962.

Del Bigio M.R., Deck J.H.N. \& Davidson G.S. 2000. Glial swelling with eosinophilia in human post-mortem brains: A change indicative of plasma extravasation. Acta Neuropathol 100:688-694.

FDA (Food and Drug Administration) 2001. Federal Register. Guidance 
for Industry: Fumonisin levels in human foods and animal feeds. U.S. Center for Food Safety and Applied Nutrition, Center for Veterinary Medicine, November 9, 2001. http://www.cfsan.fda.gov/ dms/ fumongu2.html

Foreman J.H., Constable P.D., Waggoner A.L., Levy M., Eppley R.M., Smith G.W., Tumbleson M.E. \& Haschek W.M. 2004. Neurologic abnormalities and cerebrospinal fluid changes in horses administered fumonisin B1 intravenously. Vet. Intern. Med.18:223-230.

Frisvad J.C., Smedsgaard J., Samson R.A., Larsen T.O. \& Thrane U. 2007. Fumonisin B2 production by Aspergillus niger. J. Agric. Food Chem. 55:9727-9732

Galey F.D. 2009. Disorders caused by toxicants, p.1706. In: Smith B.P. (Ed.), Large Animal Internal Medicine. $4^{\text {th }}$ ed. Mosby Elsevier, Missouri, USA.

Johnson D.J., Ostlund E.N., Pedersen D.D. \& Schmitt B.J. 2001. Detection of North American West Nile virus in animal tissue by a reverse transcription-nested polymerase chain reaction assay. Emerg. Infect. Dis. 7:739-741.

Kellerman T.S., Marasas W.F.O., Thiel P.G., Gelderblom W.C.A., Cawood M. \& Coetzer J.A.W. 1990. Leukoencephalomalacia in two horses induced by oral dosing of fumonisin B1. Onderstepoort J. Vet. Res. 57:269-275.

Lawrence G.L., Gilkerson J., Love D.N., Sabine M. \& Whalley J.M. 1994. Rapid, single-step differentiation of equid herpesviruses 1 and 4 from clinical material using the polymerase chain reaction and virus-specific primer. Virological Methods 47:59-72.

Marasas W.F.O., Kellerman T.S., Gelderblom W.C.A., Coetzer J.A.W., Thiel P.G. \& van der Lugt J.J. 1988. Leukoencephalomalacia in a horse induced by fumonisin B1 isolated from Fusarium moniliforme. Onderstepoort J. Vet. Res. 55:197-203.

Maxie M.G. \& Youssef S. 2007. Nervous system, p.358-359. In: Maxie M.G. (Ed.), Jubb, Kennedy, and Palmer's Pathology of Domestic Animals. Vol.1. $5^{\text {th }}$ ed. Saunders Elsevier, Philadelphia, PA.

Merrill A.H. Jr, Wang E., Vales T.R., Smith E.R., Schroeder J.J., Menaldino D.S., Alexander C., Xia J., Liotta D.C., Meredith F.I. \& Riley R.T. 1996. Fumonisin toxicity and sphingolipid biosynthesis. Adv. Exp. Med. Biol. 392:297-306.

Mirocha C.J., Chen J., Xie W., Xu Y., Abbas H.K. \& Hogge L.R. 1996. Biosynthesis of fumonisin and aal derivatives by Alternaria and Fusarium in laboratory culture. Adv. Exp. Med. Biol. 392:213-224.

Monina M.I., Mascotena E.A., Ruager J., Idiart J.R., Reinoso E.H., Muro A., Nosetto E.O. \& Pons E.R. 1981. Leucoencefalomalacia equina: casos registrados en el pais. Revta Mil. Vet. 28:13-17.

NTP (National Toxicology Program) 2001. Toxicology and carcinogenesis studies on fumonisin B1 in F344/N rats and B6CF1 mice (feed studies). Technical Report Series N496. NTH Publication no.013955. U.S. Department of Health and Human Services, National Institute of Health Research, Triangle Park, NC.

Ostlund E.N. 2008. West Nile Fever, p.377-385. In: OIE (Ed.), Manual of Diagnostic Tests and Vaccines for Terrestrial Animals. Chapter
2.1.20. Available on-line <http://www.oie.int/en/international-standardsetting/terrestrial-manual/access-online>

Pacin A.M., Ciancio Bovier E., González H.H.L., Whitechurch E.M., Martínez E.J. \& Resnik S.L. 2009. Fungal and fumonisins contamination in Argentine maize (Zea mays L.) silo bags. J. Agric. Food Chem. 57(7):2778-2781.

Rheeder J.P., Marasas W.F. \& Vismer H.F. 2002. Production of fumonisin analogs by Fusarium species. Appl. Environ. Microbiol. 68(5):21012105.

Riet-Correa F., Meireles A.M., Barros C.S.L. \& Gava A. 1998. Equine leukoencephalomalacia in Brazil, p.479-482. In: Garland T. \& Barr A.V. (Eds), Toxic Plants and other Natural Toxicants. CAB International, Wallingford, UK.

Riet-Correa G., Duarte M.D., Cerqueira V.D. \& Riet-Correa F. 2007. Leucoencephalomalacia in mules in northern Brazil, p. 256-262. In: Panter K.E., Wierenga T.L. \& Pfister J.A. (Eds), Poisoning Plants. Global research and Solutions. CABI, Wallingford, Oxon, UK.

Rooney J.R. \& Robertson J.L. 1996. Nervous System, p.324-325. In: Ibid. (Eds), Equine Pathology. lowa State University Press, Ames.

Ross P.F., Rice L.G., Reagor J.C., Osweiler G.D., Wilson T.M., Nelson H.A., Owens D.L., Plattner R.D., Harlin K.A., Richard J.L., Colvin B.M. \& Banton M.I. 1991. Fumonisin B1 concentrations in feeds from 45 confirmed equine leukoencephalomalacia cases. J. Vet. Diagn. Invest. 3:238-241.

Shephard G.S., Thiel P.G., Stockenstrom S. \& Sydenham E.W. 1996. Worldwide survey of fumonisins contamination of corn and cornbased products. J. AOAC Int. 79:671-887.

Solovey M.M.S., Somoza C., Cano G., Pacin A.M. \& Resnik S.L. 1999. A survey of fumonisins, deoxynivalenol, zearalenone and aflatoxins contamination in corn-based food products in Argentina. Food Additives and Contaminants 16(8):325-329.

Summers B.A., Cummings J.F. \& de Lahunta A. 1995. Degenerative diseases of the central nervous system, p.270-271. In: Ibid. (Eds), Veterinary Neuropathology. Mosby-Year Book Inc., St Louis, MO.

Tomimoto H., Akiguchi I., Wakita H., Suenaga T., Nakamura S. \& Kimura J. 1997. Regressive changes of astroglia in white matter lesions in cerebrovascular disease and Alzheimer's disease patients. Acta Neuropathol 94:146-152.

Uhlinger C. 1997. Leukoencephalomalacia. Vet. Clin. North Am., Equine Pract. 13(1):13-20.

WHO 2002. International Agency for Research on Cancer (IARC), World Health Organization, IARC Monographs on the Evaluation of Carcinogenic Risks to Humans, Lyon, 82:301-366.

Wilson T.M., Ross P.F., Owens D.L., Rice L.G., Jenkins S.J. \& Nelson H.A. 1992. Experimental production of ELEM, a study to determine the minimum toxic dose in ponies. Mycopathology 117:115-120.

Wu F. 2006. Bt Corn's reduction of mycotoxins: Regulatory decisions and public opinion, p.179-200. In: Just R.E., Alston J.M. \& Zilberman D. (Eds), Regulating Agricultural Biotechnology: Economics and Policy. Vol.30, Part 1. $2^{\text {nd }}$ ed. Springer, New York. 